\author{
A.B. Kuzembayeva, B.M. Balaubayeva \\ Al-Farabi Kazakh National University, Almaty, Kazakhstan \\ (E-mail:akuzembayeva@bk.ru)

\section{Women's empowerment issue: a new platform for the EU-Kazakhstan cooperation}

\begin{abstract}
Women's empowerment and gender equality feature prominently in the new European Union Strategy for Central Asia. They are referred to as cross-cutting issues, included in a wide range of areas such as human rights, private sector development, education, and job creation or preventing violent extremism. The EU positions itself as a reliable partner in designing and implementing adjustment policies in the region, having a strong interest in seeing Central Asia as a stable, rules-based and connected area. The objective of EU is to assist states to build its resilience through knowledge-sharing (training, monitoring, mentoring and advising) and financial aid. The EU acts as a facilitator, a mentor and a partner to enhance collaboration and partnerships to build resilient and responsive state. The strategy does link resilience to democracy. The EU continues to rhetorically support the discourse of "universal" liberal values such as a "rights-based" approach, good governance, democratization, modernization, accountability, free markets, etc. In order to enhance democracy, supporting women's empowerment is a critically important. The EU had developed a broad range of practices in gender equality and we believe that the adequate application the European model of gender equality could contribute to the implementation of an effective policy in this sphere in Kazakhstan and will expand EU-Kazakhstan mutual understanding and cooperation.
\end{abstract}

Keywords: EU, Central Asia, normative power, resilience, strategy, women's empowerment, gender equality.

\title{
Introduction
}

In 2019, the EU presented a new strategy for improving connectivity and cooperation between the EU and Central Asia. During the recent years, the European Union has become a full-fledged in Central Asia. It has strengthened its diplomatic presence and created new mechanisms for cooperation. The EU new extensive policy document reflects the previous lessons learned in years and substantive inputs by the EU and Central Asian states. The new strategy puts a new emphasis on promoting resilience, prosperity, and regional cooperation. Resilience has emerged as a key message in this strategy. Resilience is perceived as the capacity of states and societies to reform, thereby resisting and reeling from domestic and external crisis. The resilience epitomizes a shift in state-building discourses and practices from the liberal peace's emphasis on top-down institution-building to a bottom-up approach to organizing capacity-building support [1]. At this point, the resilience reorients local resources and practices and away from ready-made solutions, thus it lays a common ground for engagement.

The objective of EU is to assist states build their resilience through knowledge-sharing (training, monitoring, mentoring and advising) and financial aid. Accordingly, the EU can act as a facilitator, a mentor and a partner to enhance collaboration and partnerships to build resilient and responsive states. All this require promotion of inclusive and participatory governance, enhancement of human rights and constructive state-society relations.

In particular, the new Strategy addressed the question of the women's rights as critical agents of change. Fostering women's empowerment has featured prominently in the Strategy, which has been incorporated as crosscutting issue in such areas as human rights promotion, eliminating violence against women, private sector development, education and job creation, preventing violent extremism. It is a good opportunity for EU and Kazakhstan as well as other Central Asian states makes work these matters through continuous dialogue and concrete projects [2].

Since its independence, Kazakhstan has attached great importance to the incorporation of European standards into national regulations. Following the adoption of the new EU "road map" for Central Asia, it can be assumed that the EU-Kazakhstan further interaction also would include a two-way dialogue on different areas, including enhancing women's mobilization in different areas. 


\section{Methodology}

The article focuses on the EU new strategy for Central Asia on building a more resilient society in the region and its role in opening up new perspectives of bilateral EU-Kazakhstan cooperation in such areas as supporting the development of human resources, including women's empowerment. The article uses an exploratory research design. The article is not intended to prove a specific causality. A document analysis approach also was followed in the present study. The document analysis is based on both primary and secondary sources. The primary sources include official documents of the EU, Kazakhstan government that assisted to reveal meaning, develop understanding, and discover insights relevant to the research problem. The secondary sources used consist of a combination of academic publications, newspapers from specialized media and reports by think tanks and research institutes.

\section{Literature review}

An analysis of the academic studies on the EU foreign policy indicated that from the beginning, the EU's external relations have been described by "a fundamental tension between a long-term reformist agenda and the aim to increase European security in the short term" [3]. EU is mostly characterized as a normative actor whose foreign policy goals and implementation methods are based on soft power resources. Normative power concept grounds its roots in social constructivism. Within this approach, the EU construct itself as 'liberal empire' and the power of the EU ideas relies on its capability to diffuse to others [4]. Normative power is determined by 'contagion, informational diffusion, procedural diffusion, transference, overt diffusion and the cultural filter'. The EU diffuses its norms by using non-violent means and that is why 'the most important factor shaping the international role of the EU is not what it does or what it says, but what it is'. In its previous Strategy for Central Asia, the EU considered good governance, the rule of law, democracy and the respect for human rights as the most important normative conditions to establish and guarantee security [5]. This choice stemmed from the fact that the EU found itself as a 'role model' and through its value-based initiatives (education, civil society and mass media promotion) and civil operations (border management, drug trafficking) sought to project its normative power in the region [6].

New resilience-building strategy of 2016 fits the EU image that takes a more facilitative and advisory approach, exercising a 'softer' sort of power [7]. The new resilience paradigm stipulates a much more pragmatic approach to international involvement. For instance, Schmidt argues that resilience is a more appropriate, realistic and much more promising source of empowerment by shifting focus from causal forces to consequences [8]. Theoretically, principled pragmatism implies that the EU should act in accordance with universal values (liberal ones in this case), but then follow a pragmatic approach which denies the moral imperatives of those universal categories. It is important to note that resilience is not a realist or neo-realist strategy as understood in International Relations theory. It is infusion component of realism into the achievement of universal values; in other words, "a rejection of liberal utopianism, but not of liberal ideals themselves" or "Realpolitik with European characteristics" [9]. Such principled pragmatism addresses the feasibility of power and interests while acknowledging that the norms can only be advanced when they are "anchored in a supportive configuration of power and interest" [10].

One thing is certain: resilience is connected to a liberal narrative. Building resilience is regarded as a transformative process, but this transformation closely follows a liberal strategy. According to the European Union's Global Strategy, building resilience encourages to sustainable growth and viable societies. The strategy does link resilience to democracy: "A resilient society featuring democracy, trust in institutions, and sustainable development lies at the heart of a resilient state" [11]. Hence, it marks that the EU continues to rhetorically support the discourse of "universal" liberal values such as a "rights-based" approach, good governance, democratisation, modernisation, accountability, free markets, etc.

The new EU Strategy for Central Asia confirms above-mentioned assumptions. It is called for a more pragmatic partnership "based upon strong mutual interests"; a "modern and non-exclusive" partnership to enable the region to become "a sustainable and closely interconnected economic and political space"; and a more resilient partnership "in anticipating and addressing the challenges" of socio-economic goals and security of the wider region [12]. The new strategy had better reflect the understanding of the region. The EU positions itself as a reliable partner in designing and implementing adjustment policies in the region, having a strong interest in seeing Central Asia as a stable, rules-based and connected area. The new strategy hence aims to forge a "stronger, modern and non-exclusive partnership with Central Asia". 'Resilience' in the new strategy quickly turns into an old rehearsal of democracy promotion, human rights, rule of law, and good governance 
[13]. Jos Boonstra emphasized that the document is clear on the human rights issue as an essential element of relations [14]. Concerns about EU values which is being sacrificed for the sake of 'principled pragmatism' have not materialized. Instead, the EU avails itself of this opportunity to meet its commitment to strengthen grass-roots democracy within the Central Asian countries - in Uzbekistan and Kazakhstan in particular [13].

In order to enhance democracy, supporting women's empowerment is a critically important. The EU had developed a broad range of practices in gender equality and we believe that the adequate application the European model of gender equality could contribute to the implementation of an effective policy in this sphere in Kazakhstan and will expand EU-Kazakhstan mutual understanding and cooperation.

\section{Women's empowerment policy in the EU}

The European experience might help Kazakhstan (and maybe other Central Asian partners) to bring new impetus to their gender equality policies. In Europe "women's agenda" is prioritized at the national state and the regional levels for a long time now. In most of the European countries, governments provide wide-ranging support to facilitate gender mainstreaming in planning and programming. In Sweden, for instance, there are specific government agencies like Special Minister for gender equality and Gender Equality Coordinator. The Swedish Government has also launched development program to strengthen gender mainstreaming in 59 government agencies [15].

Governments and political parties in the EU have established legislative and voluntary quotas to gender parity in politics. France, Belgium, Italy, Spain, and Portugal all elect their parliaments by relying on the quota system. Norway, Germany and Denmark adopted the quota for corporate boardrooms. Nowadays, parliament members in the EU comprised $69.8 \%$ men and $30.2 \%$ women [16].

At the EU level, the European Commission endeavors to focus on advancement equality in decisionmaking, preventing gender-based violence and promoting women's rights worldwide under its Strategic Engagement for Gender Equality for 2016-2019. At the EU level, the European Commission endeavors to focus on advancement equality in decision-making, improving reconciliation and balance between work and family life, preventing gender-based violence and promoting women's rights worldwide under its Strategic Engagement for Gender Equality for 2016-2019 through sharing of best practices between member states, raising awareness and funding projects. The Commission seeks to address low representation of women in the labor market by rational division of family-related responsibilities between both genders within the Directive on Work-Life Balance for Parents and Careers [17]. In 2018, as the part of the EU's Rights, Equality and Citizenship programme, 3.7 million has been allocated to projects to encourage gender parity in public forums, in decision-making positions in politics and in the corporate sector and15 million were granted to projects on preventing and addressing gender-based violence. Under its 'Daphne initiative' which had been incorporated into Rights, Equality and Citizenship Programme, the Commission is funding activities as transnational networks, mutual learning and awareness-raising aimed at eliminating gender-based violence [18]. The Commission follow up on the developments by relying on the European Institute for Gender Equality.

Furthermore, the EU has also involved civil society in advancing women's rights. The largest umbrella organization of women's associations in the EU is the European Women's Lobby (EWL). The EWL launched its campaign for the 2019 European Parliament elections '50/50: Women for Europe, Europe for Women' of the EWL, which aims to achieve equal representation of women and men in institutions at EU level.

Women's empowerment has also become an essential element of the EU's foreign policy areas such as development aid or security policy. The EU views women as a resource for peace and security, who are responsible for their own well-being by attracting women into all contexts like conflict analysis, dialogue facilitation, peace building, etc. For instance, the EU has several projects aimed at helping African countries to promote women's engagement in peace and security.

According to the Council's document entitled 'Comprehensive Approach to the EU Implementation of the United Nations Security Council Resolutions 1325 and 1820 on Women, Peace and Security', there is integral relationship between the issues of peace, security, development and gender equality. This means that along with the need to encourage women's involvement in peace building, there is the necessity to bolster it by supporting development, such as the ensuring the full realization of women's economic security and rights, including access to health services and education. That can be implemented through funding for civil society's activities and working in tandem with civil society to push forward the peace process [19]. For instance, last year the EU has launched the project in Ukraine 'Women as agents of change, peace building and conflict prevention at the grassroots level in Ukraine' which is focused on promote women's contribution to conflict 
prevention processes by supporting NGO's and other local stakeholders in developing local action plans on UNSCR 1325 [20].

However, the EU catch its share of criticism for the soft law measures, since pan-European data show the slow progress in a number of areas. Women are still under-represented in decision-making positions in politics and business. In 2018, 18.4 per cent leaders of main political parties within the EU were women and only one in three deputy leaders was female. Women hold only 6.3 percent of public company board seats in the EU. Women still tend to earn on average 16 per cent less than men [21]. Regardless of shortcomings in EU practice of gender equality, Kazakhstan can gain additional experience.

\section{Assessment of current situation in Kazakhstan}

The Global Gender Gap Report — 2018 of the World Economic Forum, which is aimed to reflect genderbased disparities showed that Kazakhstan is ranked $60^{\text {th }}$ out of 149 countries and lost 28 positions at once compared to 2013. Whereas Kazakhstan has over the years made substantial progress in promoting gender equality, this has largely not translated yet in greater equality in such cases as woman taking up more senior positions or in entering male-dominated sectors like security.

Since the late of 1990s, Kazakhstan has adopted the policy of encouraging gender equality policy. Kazakhstan was the first among Central Asian countries to establish a national coordination framework for promoting gender equality through the National Commission on Women, Family and Demographic Policy. A number of policies and laws have been adopted over such as the Gender equality strategy (2006-2016), the Law of State Guarantees of Equal Rights and Equal Opportunities of Men and Women in 2009 and the 2016 Concept of Gender and Family Policy of Kazakhstan-2030.

Gender Equality for 2006-2016 was one of the main policy documents representing a comprehensive policy approach to the gender inequalities issue in Kazakhstan and considered specific tasks like increasing representation of women of at least 30 per cent at the decision making level, training and promoting womenleaders through leadership schools and other education mechanisms; encouraging a more active NGO sector. An assessment made by 'OECD Gender policy delivery review' shows many planned elements of the Strategy were only partly implemented, often due to the limited awareness and understanding among line ministries and local executive bodies of the need to adopt a gender approach; a lack of funding, gender analysis skills and tools for gender mainstreaming; and limited overall government capacity to measure policy impacts.

The Concept on Family and Gender Policy for 2030 has adopted a dual approach to gender equality, where gender considerations are embedded in all policies, laws and regulations. Yet, little attention is given to gender mainstreaming in the design and implementation of mainstream sectorial policies as well as in the development of sector-specific guidelines and development of gender-disaggregated data.

In sum, during the post-independence period and at the heart of immense political, social and economic transitions, Kazakhstan has made remarkable achievements in promoting gender equality. However, Kazakhstan had adopted only a lower level of national machineries to deal with gender mainstreaming.

Kazakhstan has performed well in several fields such as providing equal access to education. Between 2013-2018 [22], Kazakhstan has almost reached gender parity in accessing education in terms enrolment in education. Women form the majority of students at universities making up 64 per cent at master's programs and 58 per cent at PhD programs [23]. Nonetheless, there are still considerable gaps in two main indicators as "economic participation and opportunity" and "political empowerment" and these indicators have slightly decreased in 2018 compared to 2013 [22].The objective of women's $30 \%$ representation at the decision-making level in accordance with the Beijing Platform for Action, adopted at the UN's Fourth World Conference on Women has not yet been reached.

Despite extensive legislative progress, there is insufficient understanding of gender mainstreaming in Kazakhstan and it has not been institutionalized in all areas. Yet, structural inequalities like gender pay gap, the gendered division of domestic labor and care persisted. There are still considerable gaps in two main indicators as 'economic participation and opportunity' and 'political empowerment' and these indicators have slightly decreased in 2018 compared to 2013 [22].

A long road still lies ahead, and it is high time to overcome the social and cultural barriers facing women. In Kazakhstan, occupational and family role of woman are not mutually exclusive. However, greater emphasis is placed on family responsibilities. Consequently, difficulties of balancing between family life and professional responsibilities force women to shy away from administrative and leadership positions during the childrearing time, which overlap with the most demanding years of motherhood and prevent them from acquiring experience that would enable them to evolve. This indicates why women are less represented at high-level 
positions especially in such sectors as economy or security sector, which require extensive background accumulated over time during the career growth. According to the Agency for Civil Service Affairs, 9.3 percent overall of the political civil servants are women, the percentage in senior executive positions only reached 4.1 percent (corpus A). The same is true of security sector. The proportion of women in military and police sectors remains very low: women holding decision-making positions in military is 3.6 percent, percentage of police women is 11.9 [24]. A survey conducted by Institute of Equal Rights and Equal Opportunities of Kazakhstan revealed that stereotype 'politics are not a women's business' is prevailed among men, because it impedes women's access to their traditional roles, and political activity in itself is too complex for women.

Despite differences in institutions and political culture, Kazakhstan could adopt some European approaches on building alternative governance models. As a basis the EU and Kazakhstan have an Enhanced Partnership and Cooperation Agreement that gives prominence to reinforcing cooperation in 29 key policy areas, including gender equality as well as the new regional EU-Central Asia strategy that stresses gender and woman empowerment as a field of cooperation. This sets the tone for several ways to move on cooperation, experience sharing and concrete new projects.

\section{Conclusion}

The EU does not have any on-going direct programming on women's empowerment in Kazakhstan. However, in the new Joint Communication, this issue was incorporated into all other goals as a cross-cutting issue and special initiatives was offered in different areas as countering domestic violence, business-to-business dialog, education, etc. In this regard, it might be useful to set concrete goals in such critical areas as improvement of work-life balance, female entrepreneurship, gender balanced corporate boards toward their implementation within the framework of existing mechanisms such as Human Rights Dialogue and Subcommittee on Justice and Home Affairs. In addition to these, the new strategy encourages the establishment of informal "EUCentral Asia Forum". Such gatherings facilitate horizontal and vertical dialogue between local civil society organizations and governments and develop bilateral analytical cooperation on burning issues of concern, including women's empowerment.

The EU and Kazakhstan might use their cooperation in education to strengthen the role of woman in Kazakhstan's society. In the new Strategy, quality education, employability and decent job opportunities for the young population and women are of long-term strategic importance for the EU that would 'help the region to meet the demands of rapidly changing technologies and provide the skilled workforce required to pursue economic diversification and attract foreign investors'. From this perspective, Kazakhstan's current efforts to foster women's empowerment and gender equality, including improving women's employability can be more productive through initiating common EU-Kazakhstan training and exchange program (twinning) of civil servants who will be responsible for coordinating and monitoring gender mainstreaming across various government bodies. This project can also be conducted through the EU's Central Asia Education Platform (CAEP) or Erasmus+ programme.

Finally, it is important to point out that Kazakhstan and the EU take similar views toward the regional interaction. Currently Kazakhstan is classified as an upper-middle-income country and no longer needs aid, so the EU places an emphasis on capacity-building projects with a regional dimension that entails establishing partnerships on sustainable connectivity. In turn, Kazakhstan cannot disregard the necessity to revive and give substance to its relations with its Central Asian neighbors and Afghanistan. Kazakhstan has contributed to the peace process and reconstruction of Afghanistan. In 2018, Kazakhstan, during its chairmanship-in-office of the UN Security Council, attached particular importance to regional challenges and Afghanistan, which are forced to confront numerous challenges, including increased terrorism, violent extremism, drug production and trafficking. Women could play an important role in stabilization efforts. Last year, the EU together with Kazakhstan and Uzbekistan decided to launch programme that will train and educate Afghan women in Central Asia. In the New Strategy for Central Asia, the EU reiterated its intention to pursue this course. The EU and Kazakhstan could extend this program or launch another one to help Afghani women improve their economic status.

The adoption of the new EU Strategy for Central Asia shows that EU tries to strengthen its visibility in Central Asia. Besides reiterating its call for the norms and values, the new joint communication voiced the EU's intention to advance its core political, economic and security interests across Central Asia through offering specific measures. All in all, the EU would increasingly play to its distinctive strengths through those areas in which it is most admired like education and investing in youth, regional cooperation, economic 
modernization. Introducing new forms of dialogue on human rights issues like women's empowerment would have 'a real impact' and it is a new platform for convergence between the EU and Kazakhstan.

\title{
References
}

1 Chandler D. International statebuilding and the ideology of resilience // Politics. — 2013. - 33(4). - P. $276-286$.

2 Kuzembayeva A. Potential for EU-Kazakhstan cooperation on women's empowerment. — URL: https://eucentralasia.eu/2019/07/potential-for-eu-kazakhstan-cooperation-on-womens-empowerment/

3 Demmelhuber T., Kaunert C. The EU and the Gulf Monarchies: Normative Power Europe in Search of a Strategy for Engagement // Cambridge Review of International Affairs. — 2014. - No. 27(3). - P. 575.

4 Manners I. Normative Power Europe: A Contradiction in Terms? // Journal of Common Market Studies. — 2002. — No. 2(40). - P. 235-258.

5 Spaiser O.A. The EU as a Security Actor in Central Asia: Minor but not Marginal // L'Europe en Formation. — 2015. — No. 1(375). - P. 83-105.

6 Anghelescu, A.-M. European Union and Central Asia — Past Directions and Future Perspectives. — 2018.

7 Jonathan J. Varieties of Resilience: Studies in Governmentality. — Cambridge: Cambridge University Press, 2018. — P. 135.

8 Schmidt J. Intuitively neoliberal? Towards a critical understanding of resilience governance // European journal of international relations. - 2015. - No. 21(2). - P. 416.

9 Biscop S. The EU global strategy: realpolitik with European characteristics // Security policy brief. — 2016. — No. 75, June. Brussels: Egmont - The Royal Institute for International Relations. - P. 1-2.

10 Snyder J., Vinjamuri L. Principled pragmatism and the logic of consequences // International Theory. — 2012. — No. 4. — P. 438.

11 A Global Strategy for the European Union's Foreign And Security Policy. Shared Vision, Common Action: A Stronger Europe. June, 2016. — URL: https://eeas.europa.eu/archives/docs/ top_stories/pdf/eugs _ review_web.pdf

12 Joint Communication on the EU and Central Asia: New opportunities for a stronger partnership. — URL: https://eeas.europa.eu/sites/eeas/files/joint_communication_-_the_eu_and_central_asia_-_new_opportu nities_for_a_stronger_partnership.pdf

13 Korosteleva E., Bossuyt F. The EU and Central Asia: New opportunities or 'the same old song'? Retrieved from https://www.dahrendorf-forum.eu/the-eu-and-central-asia-new-opportunities-or-the-same-old-song/

14 Boonstra J. Enough to do for the EU in Central Asia. — URL: https://eucentralasia.eu/2019/06/new-eu-strategy-for-centralasia-first-reactions/

15 Gender equality policy in Sweden. - URL: https://www.government.se/4adb29/contentassets/efcc5a15ef154522a872d8e 46ad69148/gender-equality-policy-in-sweden

16 Statistical note on gender balance in politics: current situation and trends. — URL: https://eurogender.eige. europa.eu/system/files/events-files/gsd_note_wop.pdf

17 European Union: New Directive on Work-Life Balance for Parents and Caregivers. — URL: https://www.loc.gov/law /foreignnews/article/european-union-new-directive-on-work-life-balance-for-parents-and-caregivers/

18 Implementation of the Daphne programme and other funds aimed at fighting violence against women and girls. - URL: https://www.europarl.europa.eu/RegData/etudes/ STUD/2019/608857/IPOL_STU (2019) 608 857_EN.pdf

19 Revised indicators for the Comprehensive approach to the EU implementation of the UN Security Council Resolutions 1325 and 1820 on women, peace and security. — URL: http://data.consilium.europa.eu/doc/document/ST-12525-2016-INIT/en/pdf

20 Women as agents of change, peace building and conflict prevention at the grassroots level in Ukraine. - URL: https://eeas.europa.eu/delegations/peru/63644/women-agents-change-peace-building-and-conflict-prevention-grassroots-level-ukraine_en

212018 Report on equality between women and men in the EU. — URL: https://op.europa.eu/en/publication-detail/-/publication/950dce57-6222-11e8-ab9c-01aa75ed71a1

22 The Global Gender Gap Report 2018. — URL: http://www3.weforum.org/docs/WEF_GGGR_2018.pdf

23 OECD Gender Policy Delivery Review: Kazakhstan Highlights. — 2017.

24 URL: Stat.gov.kz

$25 \mathrm{EU}$ grant to enable Afghan women to study in Uzbekistan, Kazakhstan. - URL: https://central.asianews.com/en_GB/articles/cnmi_ca/features/2019/08/27/feature-02

\section{А.Б. Күзембаева, Б.М. Балаубаева}

\section{Әйелдердің құқықтары мен мүмкіндіктерін кеңейту мәселесі: ЕО және Қазақстан ынтымақтастығының жаңа тұғырнамасы}

\begin{abstract}
Әйелдердің құқықтары мен мүмкіндіктерін кеңейту және гендерлік теңдік мәселесі Орталық Азияға арналған Еуропалық Одақтың жаңа Стратегиясында айрықша орын алады. Олар адам құқықтары, жеке секторды дамыту, білім беру немесе және орындарын құру немесе зорлық-зомбылық, экстремизмнің алдын алу сияқты салалардағы өзекті мәселелер ретінде көрінеді. ЕО Орталық Азияның ережелер мен
\end{abstract}


өзара тәуелділікке негізделген тұрақтылық аймағына айналуды көздейтін құрылымдық жаңарту саясатын әзірлеуде және жүзеге асыруда сенімді әріптес ретінде көрінеді. ЕО басты мақсаты аймақ мемлекеттерінің икемділігін нығайтуда олармен білім алмасумен (оқыту, мониторинг, тәлімгерлік және кеңес беру) және қаржылық көмек берумен айқындалады. ЕО икемді және тиімді мемлекетті қалыптастыру жолында ынтымақтастық пен серіктестікті кеңейту аясында делдал, тәлімгер және серіктес ретінде әрекет етеді. Стратегияға сәйкес, икемді мемлекетті тек демократияны дамыту арқылы құруға болады. ЕО «әмбебап» либералды құндылықтарды, оның ішінде, құқықтық негіз, тиімді басқару, демократияландыру, модернизация, есеп беру, еркін нарықтар және т.б. сияқты пікірталастарды риторикалық түрде қолдайды. Демократияны нығайтуда әйелдердің мүмкіндіктерін мен құқықтарын кеңейту өте маңызды мәселе болып табылады. ЕО гендерлік теңдікті қолдауда үлкен тәжірибе жинақтады және гендерлік теңдіктің еуропалық үлгісін тиісінше пайдалана білу арқылы Қазақстанда тиімді саясатты жүзеге асыруға ықпал етеді және ЕО мен Қазақстан арасындағы өзара түсіністік пен ынтымақтастықты кеңейтеді деп ойлаймыз.

Кілт сөздер: ЕО, Орталық Азия, нормативтік күш, икемділік, стратегия, әйелдердің құқықтары мен мүмкіндіктерін кеңейту, гендерлік теңдік.

\author{
А.Б. Кузембаева, Б.М. Балаубаева
}

\title{
Проблема расширения прав и возможностей женщин: новая платформа для сотрудничества ЕС и Казахстана
}

Вопросы расширения прав и возможностей женщин и гендерного равенства занимают видное место в новой Стратегии Европейского союза для Центральной Азии. Они отражены в качестве сквозных вопросов в рамках таких областей, как права человека, развитие частного сектора, образование и создание рабочих мест или предотвращение насильственного экстремизма. ЕС позиционирует себя как надежного партнера в разработке и реализации политики структурной перестройки в регионе, проявляя серьезную заинтересованность в превращении Центральной Азии в зону стабильности, основанную на правилах и взаимозависимости. Целью ЕС является оказание помощи государствам в укреплении их стрессоустойчивости путем обмена знаниями (обучение, мониторинг, наставничество и консультирование) и финансовой помощи. ЕС выступает в качестве посредника, наставника и партнера в деле расширения сотрудничества и партнерских отношений для создания стрессоустойчивого и эффективного государства. Согласно Стратегии, достижение стрессоустойчивости возможно через развитие демократии. ЕС продолжает риторически поддерживать дискуссию об «универсальных» либеральных ценностях, таких как правовой подход, благое управление, демократизация, модернизация, подотчетность, свободные рынки и т.д. Для укрепления демократии поддержка расширения прав и возможностей женщин является критически важным вопросом. В ЕС накоплен довольно обширный опыт в области поддержки гендерного равенства, и мы считаем, что надлежащее применение европейской модели гендерного равенства может способствовать реализации эффективной политики в этой сфере в Казахстане и расширит взаимопонимание и сотрудничество между ЕС и Казахстаном.

Ключевые слова: ЕС, Центральная Азия, нормативная сила, устойчивость, стратегия, расширение прав и возможностей женщин, гендерное равенство. 